\title{
1 First dinosaur remains from Ireland
}

3 Michael J. Simms ${ }^{1}$, Robert S. H. Smyth ${ }^{2}$, David M. Martill ${ }^{2}$ and Roger Byrne ${ }^{3}$

$4{ }^{1}$ Department of Natural Sciences, National Museums Northern Ireland, Cultra,

5 Holywood, Co. Down, BT18 0EU, Northern Ireland, UK

$6 \quad{ }^{2}$ School of the Environment, Geography and Geological Sciences, University of

7 Portsmouth, Burnaby Road, Portsmouth PO1 3QL, England, UK.

$8 \quad{ }^{3}$ deceased.

\section{ABSTRACT}

11 Several specimens from the Lias Group (Lower Jurassic) of Northern Ireland have been

12 suspected as dinosaurian in origin. Bone histology and morphology demonstrates that two

13 of these, both from the same locality in Co. Antrim, demonstrably are from dinosaurs.

14 We interpret one as the proximal end of the left femur of a basal thyreophoran

15 ornithischian, and tentatively assign it to cf. Scelidosaurus. The other is the proximal part

16 of the left tibia of an indeterminate neotheropod, perhaps a stem-averostran similar to

17 Sarcosaurus, or a megalosauroid. These are the first dinosaur remains reported from

18 anywhere in Ireland and some of the most westerly in Europe, and are among only a

19 small number of dinosaurs known from the Hettangian Stage. Two additional specimens

20 are no longer considered to be from dinosaurs. We interpret one as a surangular or

21 mandible fragment from a large marine reptile, perhaps an ichthyosaur or pliosaur; the

22 other is a polygonal fragment of Paleocene basalt.

24 Key words: Ornithischia, Theropoda, Early Jurassic, Hettangian, Northern Ireland.

\section{1. Introduction}

27 Although dramatic finds from North America, Asia and elsewhere have dominated the 
28 literature for decades, Britain remains one of the richest areas in the world in terms of

29 documented dinosaur diversity. Important faunas have been recovered from the Upper

30 Triassic (e.g. Benton et al. 2000, Whiteside et al. 2016), the Jurassic of south central and

31 eastern England (Benton and Spencer 1995) and especially the Lower Cretaceous of the

32 Isle of Wight and the Weald (Martill and Naish 2001), but elsewhere in the UK dinosaur

33 remains are less abundant. Footprints and skeletal remains have been discovered in the

34 Jurassic of Yorkshire (Whyte et al. 2010), in northern England; from the Late Triassic

35 and Early Jurassic of south Wales (Benton and Spencer 1995, Yates 2003, Martill et al.

36 2016); and the Jurassic of both western and eastern Scotland (Andrews and Hudson 1984,

37 Benton et al. 1995, Clark 2018, dePolo et al. 2018, Young et al. 2018). However, no

38 dinosaur remains have hitherto been recorded from the island of Ireland.

39 Some might attribute the apparent absence of dinosaur remains from Ireland to the

40 activities of St Patrick, whose apparent success in casting out snakes is well known, but

41 there is a more mundane explanation. The sparsity of dinosaur remains in Britain beyond

42 southern England directly reflects the geology of these regions. Suitable Mesozoic rocks

43 are poorly represented in northern and western Britain where most rocks are too old to

44 contain dinosaur remains, and this is true too across large areas of Ireland. Outside of

45 Northern Ireland there are just a few, largely concealed, patches of Mesozoic inluding

46 Triassic clastics in the Kingscourt Inlier (Simms 2009) and possibly in the Wexford

47 Outlier (Clayton et al. 1986), Jurassic clastics near Cork (Higgs and Beese 1986) and

48 Carrick-on-Suir (Higgs and Jones 2000), and a tiny patch of Upper Cretaceous Chalk in

49 Co. Kerry (Walsh 1966).

50 Substantial Mesozoic basins are present in the north-east (Larne-Lough Neagh Basin) and

51 north-west (Foyle-Rathlin Basin) of Northern Ireland but they are mostly concealed

52 beneath younger rocks and exposure is confined largely to a narrow strip around the

53 margins of the Paleocene basalt plateau (Fig. 1). Triassic, Jurassic and Cretaceous strata

54 are all represented (Fig. 2) but there is a gap, representing at least 100 million years,

55 between the youngest preserved Jurassic strata (early Pliensbachian) and oldest preserved

56 Cretaceous (early Cenomanian), caused by pre-Cenomanian erosion of earlier Mesozoic

57 strata, and in places the Jurassic is cut out altogether where Cretaceous strata rest directly

58 upon Triassic or even older rocks. 
59 However, despite being of the right age to contain dinosaurs these Mesozoic strata are

60 developed in facies that do not favour the preservation of terrestrial vertebrates. The

61 Jurassic and Cretaceous strata here are entirely of open marine facies in which dinosaur

62 fossils are unlikely to be common, while the Upper Triassic succession is largely non-

63 marine and developed in red-bed facies of the Mercia Mudstone Group (Milroy et al.

64 2019) in which fossils of any kind are rarely preserved. In short, Ireland's rocks are either

65 of the wrong age or of the wrong type to contain dinosaur fossils.

66 Palaeogeographic reconstructions (Cope et al. 1992) suggest that at times during the

67 Mesozoic dinosaurs could have walked on dry land across parts of what is now Ireland.

68 However, if any rocks were deposited here at these times they were either removed long

69 ago by erosion, along with any dinosaur remains that they might contain, or they were

70 deposited in environments distant from dinosaur habitats. Finding an Irish dinosaur might

71 seem a hopeless task but, nonetheless, several potential candidates have been identified

72 and are described for the first time here.

74 2. Occurrence and history of discovery

75 Several specimens from Northern Ireland, now held in the collections of National

76 Museums NI, have been identified as potentially of dinosaurian origin. One of these

77 (BELUM K1642) was acquired in 1920 from the Belfast Natural History and

78 Philosophical Society, in existence since 1821. Information with the specimen states only

79 that it is from the "Lower Lias, Glenarm, Co. Antrim" and that possibly it was collected

80 in the late $19^{\text {th }}$ or early $20^{\text {th }}$ century by William Gray (1830-1917), a well-known

81 collector of fossils and antiquities and an ardent campaigner for a municipal museum in

82 Belfast. The Lias Group is not exposed in situ in the immediate vicinity of the town of

83 Glenarm but it is seen in landslips adjacent to the coast road at Straidkilly, to the north-

84 west of the town (NI grid ref. D305163; $54.976^{\circ} \mathrm{N},-5.96^{\circ} \mathrm{W}$ ), and Minnis North, to the

85 south-east (NI grid ref. D337137; $54.951^{\circ} \mathrm{N},-5.91^{\circ} \mathrm{W}$ ), and this bone probably originates

86 from one or other of these sites. At Straidkilly the succession extends no higher than the

87 Planorbis Zone but at Minnis North it encompasses the entire Hettangian Stage, and

88 perhaps the base of the succeeding Sinemurian Stage. However, without further 
89 information we can state only that the source of this specimen is 'probably Hettangian'.

90 The three remaining specimens (BELUM K3998, K12493, K2015.1.54) were recovered

91 from among boulders and shingle on the beach near the Gobbins, on the east coast of

92 Islandmagee, Co. Antrim (Grid ref. J485968; $54.799^{\circ} \mathrm{N},-5.690^{\circ} \mathrm{W}$ ), by the late Roger

93 Byrne between 1980 and 2000. Along the Gobbins coast the Antrim Lava Group basalts

94 (Paleocene) and Ulster White Limestone Formation (Cretaceous, Santonian to

95 Campanian) have slumped on the less mechanically competent lithologies of the Lias

96 Group (Jurassic, Hettangian) and Hibernian Greensands Formation (Cretaceous,

97 Cenomanian to Coniacian) beneath. The succession is highly disturbed but small

98 exposures at the rear of the beach and among the boulders on the foreshore expose sand

99 and silt facies of the Hibernian Greensand Formation lying unconformably upon grey

100 clays and subordinate muddy limestones of the Lias Group (Planorbis Zone) and the

101 upper Cotham Member of the Penarth Group (Triassic, Rhaetian Stage).

102 The Gobbins beach itself, extending south from the famous Gobbins cliff path, is covered

103 with rounded fragments of basalt and white limestone. Fossil material is sparse and often

104 heavily abraded. The specimens found by Roger Byrne were ex situ and hence might

105 originate from any level in the local Mesozoic succession, but comparison with other

106 vertebrate material from the Northern Ireland Mesozoic is instructive in establishing their

107 probable source. The prevailing colour of the bone in these specimens is a very dark

108 brownish-black, similar to marine vertebrate material recovered from Lias Group

109 mudstones at various sites in Northern Ireland but distinct from the dark chocolate brown

110 colour of bones and teeth found in the Hibernian Greensand or the pale brown colour of

111 those from the Ulster White Limestone. Furthermore, a small patch of grey indurated

112 calcareous mudstone on one of the specimens (K3998), and a pale grey micrite infill of

113 the medullary cavity in another (K12493), resemble Lias Group lithologies but are

114 distinct from lithologies in the Penarth Group or Chalk Group (Ulster White Limestone

115 and Hibernian Greensand formations) exposed hereabouts. Together these lines of

116 evidence suggest that the Gobbins specimens are from the Lias Group, and probably from

117 the Planorbis Zone at the base of the Hettangian Stage, or from Lias Group strata

118 immediately beneath often referred to as the 'Pre-planorbis Beds'. 
119 For many years the base of the Jurassic System in Britain was placed at the first 120 appearance of the ammonite Psiloceras planorbis, or its assumed correlatives

121 (Warrington et al. 1994, 2008) but in 2007 formal proposals were made to designate a

122 GSSP for this boundary. The Triassic-Jurassic boundary section at Larne, Co. Antrim, 123 was a candidate site (Simms and Jeram 2007) although it was the section at Kuhjoch, in

124 Austria, that ultimately was selected (von Hillebrandt et al. 2013) based on the first

125 occurrence of the ammonite Psiloceras spelae tirolicum. Direct biostratigraphic

126 correlation between Northern Ireland and the Kuhjoch section is not possible but the

127 proposed Stage and System boundary, as defined in Austria, corresponds to a significant

128 negative excursion in the carbon isotope curve (Ruhl et al. 2009) that has been recognised

129 in the Larne succession. It indicates that the base of the Jurassic System lies within the

130 'pre-Planorbis beds' of the Lias Group here, in the lower part of bed 22 (Simms and

131 Jeram 2007) and about three metres below the first appearance of ammonites (Psiloceras

132 erugatum) in bed 24, although recent work by Hodges (in press) suggests that the Jurassic 133 may commence lower in the succession.

\section{3. Early Jurassic dinosaurs in western Europe}

136 Dinosaur remains are uncommon in the Lower Jurassic of western Europe so even the

137 fragmentary remains described here are potentially of significance. The best known is the

138 thyreophoran ornithischian Scelidosaurus harrisoni from the Sinemurian of the Dorset

139 coast, England. The material on which Owen (1861) based his original description

140 actually encompassed two distinct animals; an armoured ornithischian represented by a

141 near complete skeleton, and a theropod represented by part of a hind limb. Bizarrely it

142 was the latter that was originally designated as the holotype, although it is the armoured

143 ornithischian that now holds the name. Several near complete skeletons of Scelidosaurus

144 are now known, all from Dorset. A second questionable thyreophoran, Lusitanosaurus

145 liasicus has been described from the Sinemurian of Portugal (Lapparent and Zbyszewski,

146 1957) and another, Emausaurus ernsti, is from the Toarcian of northern Germany

147 (Haubold 1990). Remains of several theropods are known from the Hettangian;

148 Lophostrophus airelensis (Cuny and Galton 1993) from Airel, Normandy; Sarcosaurus 
149 woodi from central England (Andrews 1921, Woodward 1908, von Huene 1932, Ezcurra

150 et al. 2020); Dracoraptor hanigani from Lavernock, south Wales (Martill et al. 2016); a

151 pedal phalanx and tooth fragment from Luxembourg (Delsate and Ezcurra 2014); and,

152 from the Sinemurian, the partial hind limb to which the name Scelidosaurus harrisoni

153 was first applied. A sauropodomorph hind limb, Ohmdenosaurus liasicus, has also been

154 described from the Toarcian of Baden-Württemberg (Wild 1978, Stumpf et al. 2015).

155 Much of this material is specifically indeterminate and even some of the named taxa,

156 such as Ohmdenosaurus, are so fragmentary that they are perhaps best considered nomina

157 dubia.

158 Slightly older taxa, from the late Triassic (Rhaetian), include a theropod dentary,

159 ?Megalosaurus cambrensis, from south Wales (Newton 1899, Galton, 2005); an

160 incomplete melanorosaurid sauropodomorph skeleton, Camelotia borealis, from the

161 Penarth Group of Somerset in south-west England (Galton 1985); various taxonomically

162 indeterminate fragments from the Westbury Formation of Newark, Nottinghamshire

163 (Martill and Dawn 1986) and Aust Cliff, near Bristol (Storrs 1994); and the basal

164 sauropodomorphs Thecodontosaurus and Pantydraco from supposedly Rhaetian fissure

165 fills in south-west England and south Wales (Galton et al. 2007, Riley and Stutchbury

166 1836, Whiteside et al. 2016). Supposed dinosaur limb bone fragments from the Penarth

167 Group at Aust Cliff, near Bristol (Galton 2005), are probably jaw fragments from giant

168 ichthyosaurs (Lomax et al. 2018).

170 4. Evidence for dinosaurs in Ireland

171 In Northern Ireland the Jurassic succession is entirely marine. Bones of marine fish and

172 reptiles, ichthyosaurs and plesiosaurs, have been recovered from many exposures of the

173 Lower Jurassic here and so our initial assumption must be that those bones we consider as

174 potentially dinosaurian in origin are, in fact, from marine vertebrates. This possibility can

175 largely be discounted. Firstly, no Lower Jurassic fish yet discovered attains a size

176 comparable with that indicated by these bones. Secondly, the shape of each of the bone

177 fragments in question does not immediately resemble any of the bones found in

178 ichthyosaur or plesiosaur skeletons, although caution must be exercised here as 
179 fragmentary ichthyosaur bones have in the past been mistaken for those of dinosaurs

180 (Lomax et al. 2018). Finally, and most significantly, the fine structure of these bones

181 differs significantly from that found in fish, ichthyosaurs or plesiosaurs/pliosaurs.

183 4.1. Bone histology and surface texture

184 The bones of Jurassic ichthyosaurs and plesiosaurs, including their long bones and

185 vertebrae, are commonly dominated by a porous or cancellous structure, with little or no

186 medullary cavity, surrounded by a compact peripheral layer (Houssaye et al. 2014, Liebe

187 and Hurum 2012) that typically is relatively thin (less than $20 \%$ of bone radius). This is

188 similar to extant cetaceans and reflects their highly evolved aquatic mode of life where

189 overall density of the animal is more critical than the load-bearing properties of the

190 bones. In contrast the load-bearing bones of terrestrial vertebrates, such as dinosaurs, tend

191 to have a more thickened (30-40\% of bone radius) outer zone of compact bone around an

192 inner core of cancellous bone and/or a medullary cavity which, in life, contains bone

193 marrow (e.g. Hübner 2012, Redelstorff et al. 2013). A further significant distinguishing

194 character is that the surface texture of dinosaur long bones is very smooth whereas those

195 of marine reptiles, including long bones, ribs and jaws, commonly tend to show a greater

196 rugosity in the form of longitudinal striations subparallel to the bone long axis.

197 The typically dinosaurian aspects of bone histology seen in K3998 were recognised as

198 early as 1989 by the late Robin Reid of Queens University Belfast, who had developed an

199 interest in dinosaur bone histology (e.g. Reid 1984), and the discovery of this specimen

200 was reported in the local press. It was Roger Byrne himself that recognised the second

201 dinosaur bone fragment from the Gobbins (K12493) based essentially on the same

202 criteria (dense outer bone and large medullary cavity). Two other potential candidates

203 (K1642 and K2015.1.54) have in the past been suggested, or suspected, as being of

204 dinosaurian origin but a closer reexamination reveals that this is not so.

205

206 4.2. Morphological descriptions

207 Bone histology and surface texture can be used to establish if these fragments are from 
208 dinosaurs, but it is their shape that we have used in our attempt to identify which bones

209 they are and from broadly which group(s) of dinosaurs they originate. Robin Reid

210 suggested in 1989 (Ulster Museum, unpublished notes) that K3998 was the proximal end

211 of a femur, perhaps from the well-known early Jurassic thyreophoran genus

212 Scelidosaurus although his reason for assigning it to that genus may have been based on

213 little more than that it being the best-known early Jurassic dinosaur. With the second

214 fragment (K12493) found at the same site it was, understandably, assumed to be from the

215 same animal as K3998. However, on the basis of their size difference alone it is

216 immediately apparent that this is not the case and the two bone fragments clearly

217 represent different individuals and distinct taxa.

218

219 4.3. Specimen descriptions and interpretation

220 4.3.1. Specimen BELUM K3998a, b

221 This specimen (Figure 3a-j) was collected by Roger Byrne on $13^{\text {th }}$ January 1980 and was

222 the first Irish dinosaur bone to be recognised, by Dr Robin Reid in 1989. It is a short

223 fragment of a bone, smooth on its outer surface, abraded at its presumed proximal end

224 and sectioned distally to reveal a thickened bone wall sharply demarcated from a lumen

225 with a very open trabecular bone fill (Fig. 3c, f). There is no evidence of a medullary

226 cavity, perhaps reflecting the proximity of this cut surface to the original bone

227 termination. A glass-mounted thin section of this cut surface is in the Ulster museum

228 collections (BELUM K3998b). The original preserved extent of the bone beyond the cut

229 surface is not known, but it is not believed to be substantial. The outline of the bone, as

230 seen laterally, is roughly quadrate. One face is broadly concave with a prominent sulcus

231 offset to one side and parallel to the long axis of the bone (Fig. 3b, e). On the other side

232 there is a prominent boss, located slightly off-centre, that is higher towards the middle

233 and fades away toward two of the margins of the subquadrate outline (Fig. 3a, d).

234 Surface texture and histology establish this specimen as a dinosaur bone and we interpret

235 it as the proximal end of a left femur, sectioned across its distal end and with the

236 proximal end abraded and missing the femoral head. What is preserved of the femoral

237 shaft is almost straight, but there is too little remaining to say anything more about shaft 
morphology. The heavily worn base of the anterior trochanter is present on the

239 anterolateral surface of the femoral shaft (Fig. 3a, d, h). A small area of matrix, on which

240 the accession number is written, remains between the proximal preserved part of the

241 anterior trochanter and the femoral shaft (Fig. 3g) and demonstrates that they were well

242 separated from each other. There is no evidence to suggest that the femoral head was

243 separated from the greater and anterior trochanters by a constriction. The anterior

244 trochanter joins with the femoral shaft via a distally expanding ridge that extends along

245 the preserved portion of the anterolateral edge of the element. A finger-like mound

246 extends proximodistally along the anteromedial surface of the shaft (Fig. 3b, e, h), and

247 presumably this structure was confluent or merged with the distal margin of the femoral

248 head. It suggests that the femoral head would have emerged gently from the shaft of the

249 femur.

250 The presence of a prominent anterior trochanter, well separated from the femoral shaft, is

251 further evidence that this specimen is from a dinosaur, while thickening of the bone wall

252 with trabecular bone is characteristic of ornithischians. Furthermore, the lack of any

253 indication of a constriction separating the femoral head from the greater and anterior

254 trochanters is a plesiomorphic trait shared by basal ornithischians to the exclusion of

255 more highly derived forms (Butler et al. 2012). BELUM K3998 is relatively large for an

256 Early Jurassic ornithischian, with ornithischian diversity at this time characterised by

257 small-bodied heterodontosaurids (Sereno, 2012) and basal thyreophorans (Norman et al.

258 2004), with no heterodontosaurid known that approaches a size even close to that of

259 BELUM K3998 (Sereno 2012). The quadrate outline of the femoral shaft of BELUM

$260 \mathrm{~K} 3998$ in cross-section is also quite unlike the subcircular and elliptical femoral shaft

261 cross-sections seen in other Early Jurassic ornithischians such as Lesothosaurus and

262 heterodontosaurids (Butler 2010, Norman 2019), but it does resemble that of the basal

263 thyreophoran Scelidosaurus. Among Early Jurassic ornithischians only Scelidosaurus and

264 Lusitanosaurus are known to attain a size comparable with that indicated by BELUM

265 K3998 (Antunes and Mateus 2003, Norman 2019), and comparison with femora of

266 Scelidosaurus (NHMUK R1111 and NHMUK R6704) does show remarkable similarities

267 (Figure 3h, k). The size and morphology of BELUM K3998, the positioning and

268 condition of the anterior trochanter, and the finger-like ridge present on its anteromedial 
269 surface, all match closely with Scelidosaurus and differ from what is seen in the

270 significantly smaller basal thyreophoran Scutellosaurus (Norman 2019, Rosenbaum and

271 Padian 2000).

273 4.3.2. Specimen BELUM K12493.

274 This bone fragment (Fig. 4a-h, k, l) was collected by Roger Byrne on $15^{\text {th }}$ April 1981. It

275 is a portion of the shaft of a long bone with a smooth outer surface, abraded proximal

276 articular surface and truncated distal section. It displays a robust lateral crista and has a

277 triangular outline proximally with a sub-rectangular cross section distally (Fig. 4c, d).

278 The proximal cross section is damaged, probably due to post-burial compaction, and

279 reveals a thickened bone wall sharply demarcated from a lumen containing vacuous

280 trabecular bone, with voids tending to be larger toward one side (Fig. 4c, k). The distal

281 cross section reveals a somewhat thicker bone wall with a subcircular lumen (about 50\%

282 of bone diameter) that lacks trabecular bone. Most of this cavity is filled with pale grey

283 micritic limestone but about the remaining third contains a pale, off-white, geopetal

284 calcite infill containing small angular bone shards (Figure 4d, 1). In both cross-sections

285 the thickened bone displays a number of lines of arrested growth (LAGs) suggesting

286 development under a seasonal climate (sensu Köhler et al. 2012). There is a flattened to

287 weakly concave surface along one length of the diaphysis that we presume was occupied

288 by an adjacent bone, as in the case of a tibia-fibula or metatarsal-metatarsal contact.

289 The surface texture and histology of this specimen establish it as a dinosaur bone, and we 290 interpret it as the worn and truncated proximal portion of a left tibia. The shaft, as

291 preserved, is straight although too little remains to infer much about its intact form. The

292 distal portion of the cnemial crest rises from the anterior surface of the shaft (Fig. 4a, e)

293 but neither medial nor lateral condyles are evident in this specimen, which we attribute to

294 these structures being confined to the, now eroded, proximal-most region of the posterior

295 side of the tibia. A large fibular crest extends proximodistally along the lateral surface of

296 the tibial shaft (Fig. 4b, f). It is somewhat expanded anteroposteriorly at the midpoint of

297 the preserved shaft and tapers towards the proximal and distal ends of the element. It was

298 most likely lens or tear-drop shaped in lateral view but, despite significant wear, there is 
no evidence of any internal bone texture exposed on the low broad crest suggesting that

300 in life it did not rise to a sharp point.

301 BELUM K12493 is a heavily abraded bone fragment lacking terminations and hence

302 identification is difficult. It does show some similarities with a proximal metatarsal 4 in

303 the Early Cretaceous theropod Neovenator salerii Hutt, Martill and Barker 1996, from the

304 Isle of Wight, but this is not an especially good match and it bears little similarity to the

305 same elements in the Late Jurassic theropod Allosaurus fragilis Marsh 1877 (see Madsen

3061976 fig. 25A). Furthermore, were this the case the size of BELUM K12493 would imply

307 the existence of an Early Jurassic theropod substantially larger than any currently known.

308 Instead its morphology is more consistent with that of a tibia, with the combination of its

309 size, prominent fibular crest, thin bone wall distally with an absence of trabecular bone,

310 and the probable basis for a large cnemial crest, attesting to the theropodan affinities of

311 this specimen. The fibular crest in particular is diagnostic, extending well into the

312 proximal end of the tibia on BELUM K12493. This is the basal condition for theropods

313 and is present in coelophysoids (Spielmann et al. 2007), dilophosaurids (Welles 1984),

314 stem-averostrans such as Sarcosaurus (Ezcurra et al. 2020), as well as ceratosaurians

315 (Madsen and Welles 2000, O'Connor 2007). Among tetanurans only some

316 megalosauroids are known to possess such a proximally extended fibular crest (Benson

317 2010a, Madsen 1976, Malafaia et al. 2018). Of these megalosauroids only a few develop

318 a crest with a low anteroposteriorly broad mound, as seen in BELUM K12493, including

319 Megalosaurus, Piatnitzkysaurus, Condorraptor, and Magnosaurus (Benson 2010a,

320 2010b, Rauhut 2005). In other megalosauroids, including Eustreptospondylus,

321 Spinosaurus, Suchomimus and Torvosaurus the fibular crest forms a narrow ridge, more

322 typical of tetanurans (Benson 2010a, Ibrahim et al. 2014, Sadleir et al. 2008). The

323 metriacanthosaurid Sinraptor also possesses an oval shaped, mound-like fibular crest, but

324 it is positioned more anteriorly on the tibial shaft and forms a more prominent ridge than

325 in either megalosauroids or BELUM K12493 (Currie and Zhao 1993).

326 The presence of an anteroposteriorly broad, proximally extended fibular crest on BELUM

327 K12493 is similar to those found on some megalosauroids, specifically the

328 Megalosauridae or Piatnitzkysauridae. It resembles the tibiae of Magnosaurus and

329 matches closely those of the Bathonian Megalosaurus bucklandi itself (particularly 
330 NHMUK PV R 12557 and OUMNH J.13562), although the latter are substantially larger

331 than that represented by BELUM K12493 (Figure 4i, j). However, BELUM K12493

332 differs from the tibia of these megalosauroids in other ways besides overall size. While

333 the fibular crest of megalosauroids emerges gently from the tibial shaft to form a low

334 mound, the crest on BELUM K12493 emerges from the tibial shaft much more abruptly.

335 Additionally, the distal termination of the fibular crest in BELUM K12493 is more abrupt

336 than those of megalosauroids which grade more gently into the bone shaft.

337 In these features BELUM K12493 bears a closer resemblance to Sarcosaurus woodi from 338 the Lias Group (Hettangian-Sinemurian) of central England (sensu Ezcurra et al. 2020).

339 Sarcosaurus was originally referred to Megalosauridae (Andrews 1921, von Huene

340 1932), but subsequent analyses of the taxon have variously placed it among

341 Coelophysidae/Coelophysoidea (Welles 1984; Carrano et al. 2005), basal Ceratosauria

342 (Ezcurra 2012), Dilophosauridae (Dal Sasso et al. 2018) and, most recently, as stem-

343 Averostra (Ezcurra et al. 2020). The size and morphology of BELUM K12493 and

344 Sarcosaurus are consistent. They are recovered from approximately coeval strata within

345 the Lias Group and their localities are within relatively close proximity $(\sim 375-390 \mathrm{~km})$.

346 Most likely, BELUM K12493 represents an animal similar to Sarcosaurus, but the

347 limitations of the material and absence of shared autapomorphies precludes any definite

348 referral to this taxon. We consider BELUM K12493 to represent an indeterminate

349 neotheropod, likely representing either a stem-averostran or a megalosauroid.

350

351

4.4. Additional specimens previously interpreted as dinosaurian

352 Two further specimens in the collections of the Ulster Museum have, in the past, been

353 suggested as of dinosaurian origin but closer examination reveals these claims to be

354 unfounded.

355

356 4.4.1. Specimen BELUM K1642

357 This specimen (Figure 5a, g-h), which has been in the museum's collection for at least a 358 century, is a straight, roughly cylindrical section of bone approximately $16 \mathrm{~cm}$ long and 
$3596.5 \mathrm{~cm}$ across. It lacks any terminations, being broken obliquely at one end and

360 terminated by a cut section at the other. In cross section it is roughly D-shaped, with the

361 curved part of the D represented by the intact rounded outer surface of the bone and the

362 straight section corresponding to a fractured surface exposing an area of cancellous bone

363 (Figure $5 \mathrm{~g}$ ). The sectioned end of the bone (Figure $5 \mathrm{~h}$ ) reveals a relatively dense, yet still

364 porous, outer layer extending through about $280^{\circ}$ and interrupted by a zone of coarsely

365 porous trabecular bone. The outer layer surrounds a relatively small ( $<40 \%$ of diameter)

366 central cavity into which traces of coarse trabecular bone penetrate.

367 The bone was loaned to Dr Robin Reid in January 1980 and returned, 6 months later,

368 with a section removed from one end but without comment from Dr Reid. He had

369 developed an interest in dinosaur bone histology at this time and so we assume that this

370 section was removed in relation to that project, on suspicion that it might be a dinosaur

371 bone, but he did not convey his thoughts to the Ulster Museum geologists at the time.

372 Superficially this fragment does resemble a dinosaur long bone shaft in its broadly

373 cylindrical shape, albeit with about a fifth of its circumference apparently broken away,

374 and its appearance in section of a distinct central lumen surrounded by relatively dense

375 bone. However, closer examination of the specimen reveals features that are not

376 consistent with this interpretation. The outer surface of K1642 is not smooth, as in

377 dinosaur long bones, but has the striated appearance (Figure 5a, g) characteristic of the

378 ribs, jaws and limb elements of ichthyosaurs (cf. fig 4 of Lomax et al. 2018) and

379 plesiosaurs/pliosaurs. Furthermore, in section the outer bone layer is substantially less

380 dense than is seen in dinosaurs, with a more conspicuously visible pattern of canals and

381 LAGs (Figure 5h, cf. fig. 4d), and coarsely porous trabecular bone that occupies and

382 extends into that section of the circumference where the outer surface appears to have

383 been broken away. This is not what we would expect to find in any dinosaur long bone

384 but invites comparison with the distal end of an ichthyosaur surangular bone, as described

385 and figured by Lomax et al. (2018). Hence, we interpret this fragment as probably a

386 fragment of surangular from a large ichthyosaur, perhaps Temnodontosaurus, or possibly

387 a mandible fragment from a pliosaur such as the rhomaleosaurid Atychodracon. 
390 In the year 2000 Roger Byrne discovered a small flat pentagonal object (Figure 5b-f) with 391 a bone-like texture amongst shingle on the Gobbins beach. By association with the 392 presumed scelidosaur femur (K3998) it was assumed that this object might be a

393 scelidosaur osteoderm, although it lacked the point or curved crest typical of osteoderms 394 in Scelidosaurus harrisoni (Norman 2019). The identity of this object remained

395 enigmatic for almost two decades. Dinosaur experts were consulted but could see no 396 evidence for dinosaurian affinity, and turtle experts similarly were baffled. It was only 397 through examination by a fresh pair of eyes (DMM) in 2019 that the mystery was finally

398 solved. It is not a bone at all but merely a small pentagonal piece of basalt! Who would

399 have thought, in the land of the Giant's Causeway, that such a remarkably regular 400 fragment of basalt could turn up on an Antrim beach? The lesson to be learned here is 401 that some of us (MJS) were perhaps too influenced by the remarkably regular shape of

402 this object and by its discovery on the same beach from which a dinosaur bone,

403 tentatively assigned to Scelidosaurus, had been recovered.

\section{5. Conclusions}

406 Several specimens from Northern Ireland have been suspected, or suggested, as dinosaur 407 bones but just two can be definitely assigned to this group on the basis of their bone 408 histology, surface texture and morphology. Both are from the base of the fully marine 409 Lias Group (Jurassic System, Hettangian Stage, probably Planorbis Zone) of the Gobbins, 410 Islandmagee, Co. Antrim. Although fragmentary and beach-worn these bones retain 411 sufficient characters for them to be identified and tentatively assigned to distinct clades.

412 We interpret BELUM K3998 as the proximal end of a left femur of a thyreopophoran 413 ornithischian, and tentatively assign it to cf. Scelidosaurus. If correct this underlines the 414 close association of Scelidosaurus with the marine Lias Group and perhaps implies 415 something about its environmental preference. We identify BELUM K12493 as the 416 proximal portion of a left tibia from a neotheropod, and most likely from either a stem417 averostran similar to Sarcosaurus, or from an indeterminate megalosauroid.

418 Reexamination of two other specimens reveals that neither are from dinosaurs. A bone 
419 fragment from the Lias Group of Glenarm (BELUM K1642), suspected as being part of

420 a dinosaur long bone, is probably a surangular or mandible fragment from a large marine

421 reptile while an enigmatic pentagonal object (BELUM K2015.1.54) from the Gobbins,

422 once thought to be a scelidosaur osteoderm, is nothing more than a small polygonal flake

423 of Paleocene basalt!

424 Hettangian dinosaurs are rare and represented only by fragmentary material from England

425 (Andrews 1921), Scotland (Benton et al. 1995) and Arizona (Lucas and Heckert 2001),

426 and perhaps also from Morocco (Nicholl et al. 2018), South Africa (McPhee et al. 2015)

427 and Antarctica (Smith et al. 2007). This global rarity emphasises the potential

428 significance of even these fragmentary remains from Northern Ireland for understanding

429 the evolution and biogeography of Early Jurassic dinosaurs.

430

431 Declaration of Competing Interest

432 The authors declare that they have no known competing financial or personal

433 relationships that could have appeared to influence the work reported in this paper.

435 Acknowledgements

436 We thank Paul Barratt, Mike Benton, Eric Buffetaut, Sandra Chapman, Angela Milner

437 and David Norman for their comments on these specimens, and the constructive

438 comments of two referees; and Patrick Collins (Queens University Belfast) for producing

439 3D scans of the two Gobbins bones for the Portsmouth team.

441 References

442 Andrews, C.W., 1921. On some remains of a theropodous dinosaur from the Lower Lias

443 of Barrow-on-Soar. Annals and Magazine of Natural History, series 9, 8, 570-576.

444 Andrews, J.E., Hudson, J.D., 1984. The first Jurassic dinosaur footprint from Scotland.

445 Scottish Journal of Geology 20, 129-134.

446 Antunes, M.T., Mateus, O., 2003. Dinosaurs of Portugal. Comptes Rendus Palevol 2, 77- 
448 Benson, R.B., 2010a. A description of Megalosaurus bucklandii (Dinosauria: Theropoda)

449 from the Bathonian of the UK and the relationships of Middle Jurassic theropods.

450 Zoological Journal of the Linnean Society 158, 882-935.

451 Benson, R.B., 2010b. The osteology of Magnosaurus nethercombensis (Dinosauria,

452 Theropoda) from the Bajocian (Middle Jurassic) of the United Kingdom and a re-

453 examination of the oldest records of tetanurans. Journal of Systematic Palaeontology 8,

454 131-146.

455 Benton, M.J., Martill, D.M., Taylor, M.A., 1995. The first Lower Jurassic dinosaur from

456 Scotland: limb bone of a ceratosaur theropod from Skye. Scottish Journal of Geology 31, 457 177-182.

458 Benton, M.J., Spencer, P.S., 1995. Fossil Reptiles of Great Britain. Geological

459 Conservation Review Series No 5, 345 pp.

460 Benton, M.J., Juul, L., Storrs, G.W., Galton, P.M., 2000. Anatomy and systematics of the

461 prosauropod dinosaur Thecodontosaurus antiquus from the Upper Triassic of southwest

462 England. Journal of Vertebrate Palaeontology 20, 77-108.

463 Butler, R.J., 2010. The anatomy of the basal ornithischian dinosaur Eocursor parvus from

464 the lower Elliot Formation (Late Triassic) of South Africa. Zoological Journal of the

465 Linnean Society 160, 648-684.

466• Butler, R.J., Porro, L.B., Galton, P.M., Chiappe, L.M., 2012. Anatomy and cranial

467 functional morphology of the small-bodied dinosaur Fruitadens haagarorum from the

468 Upper Jurassic of the USA. PLoS One 7(4). https://doi.org/10.1371/journal.pone.0031556

469 Carrano, M.T., Hutchinson, J.R., Sampson, S.D., 2005. New information on Segisaurus

470 halli, a small theropod dinosaur from the Early Jurassic of Arizona. Journal of Vertebrate

471 Paleontology 25, 835-849.

472 Clark, N.D.L., 2018. Review of the dinosaur remains from the Middle Jurassic of

473 Scotland, UK. Geosciences 2018, 8(2), 53.

474 Clayton, G., Sevastopulo, G.D., Sleeman, A.G., 1986. Carboniferous (Dinantian and 
475 Silesian) and Permo-Triassic rocks in south County Wexford, Ireland. Geological Journal 476 21, 355-374.

477 Cope, J.C.W., Ingham, J.K., Rawson, P.F. (eds), 1992. Atlas of palaeogeography and 478 lithofacies. Geological Society Memoir no. 13. xii+153 pp. London, Bath: Geological 479 Society of London.

480 Cuny, G., Galton, P.M., 1993. Revision of the Airel theropod dinosaur from the Triassic481 Jurassic boundary (Normandy, France). Neues Jahrbuch für Geologie und Paläontologie, 482 Abhandlungen 187, 261-288.

483 Currie, P.J., Zhao, X.J., 1993. A new carnosaur (Dinosauria, Theropoda) from the 484 Jurassic of Xinjiang, People's Republic of China. Canadian Journal of Earth Sciences 30, $485 \quad 2037-2081$.

486 Dal Sasso, C., Maganuco, S., Cau, A., 2018. The oldest ceratosaurian (Dinosauria: 487 Theropoda), from the Lower Jurassic of Italy, sheds light on the evolution of the three488 fingered hand of birds. PeerJ 6, e5976.

489 Desalte, D., Ezcurra, M., 2014. The first Early Jurassic (late Hettangian) theropod 490 dinosaur remains from the Grand Duchy of Luxembourg. Geologica Belgica 172, 175491181.

492 Ezcurra, M.D., 2012. Phylogenetic analysis of Late Triassic - Early Jurassic neotheropod 493 dinosaurs: Implications for the early theropod radiation. Journal of Vertebrate 494 Paleontology, Program and Abstracts 2012 32, 91.

495 Ezcurra, M.D., Butler, R.J., Maidment, S.C.R., Sansom, I.J., Meade, L.E., Radley, J.D., 496 2020. A revision of the early neotheropod genus Sarcosaurus from the Early Jurassic 497 (Hettangian-Sinemurian) of central England, Zoological Journal of the Linnean Society, , 498 zlaa054, https://doi.org/10.1093/zoolinnean/zlaa054

499 Galton, P.M., 1985. Notes on the Melanorosauridae, a family of large prosauropod 500 dinosaurs (Saurischia: Sauropodomorpha). Géobios 18, 671-676.

501 Galton, P.M., 2005. Bones of large dinosaurs (Prosauropoda and Stegosauria) from the 502 Rhaetic Bone Bed (Upper Triassic of Aust Cliff, southwest England. Revue de 503 Paléobiologie 24, 51-74. 
504 Galton, P.M., Yates, A.M., Kermack, D., 2007. Pantydraco n. gen. for Thecodontosaurus

505 caducus Yates, 2003, a basal sauropodomorph dinosaur from the Upper Triassic or

506 Lower Jurassic of South Wales. Neues Jahrbuch für Geologie und Paläontologie,

507 Abhandlungen 243, 119-125.

508 Haubold, H., 1990. Ein neuer Dinosaurier (Ornithischia, Thyreophora) aus dem Unteren

509 Jura des nördlichen Mitteleuropa. Revue de Paleobiologie 9, 149-177.

510 Higgs, K.T., Beese, A.P., 1986. A Jurassic microflora from the Colbond Clay of Cloyne,

511 County Cork. Irish Journal of Earth Sciences 7, 99-109.

512 Higgs, K.T., Jones, G.Ll., 2000. Palynological evidence for Mesozoic karst at Piltown,

513 Co. Kilkenny. Proceedings of the Geologists’' Association 111, 355-362.

514 von Hillebrandt, A., Krystyn, L., Kürschner, W.M., Bonis, N.R., Ruhl, M., Richoz, S.,

515 Schobben, M.A.N., Urlichs, M., Bown, P.R., Kment, K., McRoberts, C.A., Simms, M.,

516 Tomãsových, A., 2013. The Global Stratotype Sections and Point (GSSP) for the base of

517 the Jurassic System at Kuhjoch (Karwendel Mountains, Northern Calcareous Alps, Tyrol,

518 Austria). Episodes 36, 162-198.

519 Hodges, P., in press. A new ammonite from the Penarth Group of south Wales, and the

520 base of the Jurassic System in south-west Britain. Geological Magazine.

521 Houssaye, A., Scheyer, T.M., Kolb, C., Fischer, V., Sander, P.M., 2014. A new look at

522 ichthyosaur long bone microanatomy and histology: Implications for their adaptation to

523 an aquatic life. Plos One 4. https://doi.org/10.1371/journal.pone.0095637

524 Hübner, T.R., 2012. Bone histology in Dysalotosaurus lettowvorbecki (Ornithischia:

525 Iguanodontia) - Variation, growth, and implications. PLoS ONE 7 (1), e29958.

526 doi:10.1371/journal.pone.0029958

527 von Huene, F., 1932. Die fossile Reptil-Ordnung Saurischia, ihre Entwicklung und

528 Geschichte. Monographien zur Geologie und Palaeontologie, Serie 1, 1-361.

529 Hutt, S., Martill, D.M., Barker, M.J., 1996. The first European allosauroid dinosaur

530 (Lower Cretaceous, Wealden Group, England). Neues Jahrbuch für Geologie und

531 Paläontologie Monatshefte,1996, 635-644. 
532 Ibrahim, N., Sereno, P.C., Dal Sasso, C., Maganuco, S., Fabbri, M., Martill, D.M.,

533 Zouhri, S., Myhrvold, N., Iurino, D.A., 2014. Semiaquatic adaptations in a giant

534 predatory dinosaur. Science 345, 1613-1616.

535 Köhler, M., Marín-Moratalla, N., Jordana, X., Aanes, R., 2012. Seasonal bone growth

536 and physiology in endotherms shed light on dinosaur physiology. Nature 487(7407), 358-

537361.

538 de Lapparent, A.F., Zbyszewski, G. 1957. Les dinosauriens du Portugal, Mémoires des

539 Services Géologiques du Portugal, nouvelle série 2, 1-63.

540 Liebe, L., Hurum, J.H. 2012. Gross internal structure and microstructure of plesiosaur

541 limb bones from the Late Jurassic, central Spitsbergen. Norwegian Journal of Geology

542 92, 285-309.

543 Lomax, D.R., De la Salle, P., Massare, J.A., Gallois, R., 2018. A giant Late Triassic

544 ichthyosaur from the UK and a reinterpretation of the Aust Cliff 'dinosaurian' bones.

545 PLoS ONE 13(4): e0194742. https://doi.org/10.1371/journal.pone.0194742

546 Lucas, S.G., Heckert, A.B., 2001. Theropod dinosaurs and the Early Jurassic age of the

547 Moenave Formation, Arizona-Utah, USA. Neues Jahrbuch für Geologie und

548 Paläontologie Monatshefte 2001, 435-448.

549 Madsen, J.H., 1976. Allosaurus fragilis: A Revised Osteology. Utah Geological Survey

550 Bulletin 109, $177 \mathrm{pp}$.

551 Madsen, J.H., Welles, S.P., 2000. Ceratosaurus (Dinosauria, Theropoda): a revised

552 osteology. Utah Geological Survey, 89 pp.

553 Malafaia, E., Gasulla, J.M., Escaso, F., Narváez, I., Sanz, J.L., Ortega, F., 2018. New

554 spinosaurid (Theropoda, Megalosauroidea) remains from the Arcillas de Morella

555 Formation (upper Barremian) of Morella, Spain. Cretaceous Research 92, 174-183.

556 Marsh, O. 1877. Notice of new dinosaurian reptiles from the Jurassic formations.

557 American Journal of Science (3) 14, 514-516.

558 Martill, D. M., Dawn, A., 1986. Fossil vertebrates from new exposures of the Westbury

559 Formation (Upper Triassic) at Newark, Nottinghamshire. Mercian Geologist 10, 127-133. 
560 Martill, D.M., Naish, D. (eds), 2001. Dinosaurs of the Isle of Wight. Palaeontological

561 Association,Field Guides to Fossils Series no. 10, 433 pp.

562 Martill, D.M., Vidovic, S.U., Howells, C., Nudds, J.R., 2016. The Oldest Jurassic

563 Dinosaur: A Basal Neotheropod from the Hettangian of Great Britain. PLoS ONE, 11 (1):

564 e0145713. pmid:26789843

565 McPhee, B.W., Bonnan, M.F., Yates, A.M., Neveling, J., Choiniere, J.N., 2015. A new

566 basal sauropod from the pre-Toarcian Jurassic of South Africa: evidence of niche-

567 partioning at the sauropodomorph-sauropod boundary. Scientific Reports 5, 13-24.

568 Milroy, P., Wright, P.V, Simms, M.J., 2019. Dryland continental mudstones: deciphering

569 environmental changes in problematic mudstones from the Upper Triassic (Carnian to

570 Norian) Mercia Mudstone Group, south-west Britain. Sedimentology 66, 2557-2589.

571 Newton, E.T., 1899. On a megalosaurid jaw from the Rhaetic beds near Bridgend

572 (Glamorganshire). Quarterly Journal of the Geological Society of London 55, 89-96.

573 Nicholl, C.S.C., Mannion, P.D., Barrett, P.M. 2018. Sauropod dinosaur remains from a

574 new Early Jurassic locality in the Central Hight Atlas of Morocco. Acta Palaeontologica

575 Polonica 63, 147-157.

576 Norman, D.B., Witmer, L.M., Weishampel, D.B., 2004. Basal thyreophora. In The

577 Dinosauria: Second Edition (pp. 335-342). University of California Press.

578 Norman, D.B. 2019. Scelidosaurus harrisonii from the Early Jurassic of Dorset, England:

579 postcranial skeleton. Zoological Journal of the Linnean Society XX, 1-111.

580 O'Connor, P.M., 2007. The postcranial axial skeleton of Majungasaurus crenatissimus

581 (Theropoda: Abelisauridae) from the Late Cretaceous of Madagascar. Journal of

582 Vertebrate Paleontology 27, 127-163.

583 Owen, R., 1849-1884. A History of British Fossil Reptiles. Cassell, London. 657 and 199 584 pp, 2 vols plates.

585 Owen, R., 1861. A monograph of a fossil dinosaur (Scelidosaurus harrisonii, Owen) of

586 the Lower Lias, part I. Monographs on the British fossil Reptilia from the Oolitic

587 Formations 1 pp 14 
588 dePolo, P.E., Brusatte, S.L., Challands, T.J., Foffa, D., Ross, D.A., Wilkinson, M., Yi, H589 y., 2018. A sauropod-dominated tracksite from Rubha nam Brathairean (Brothers' Point), 590 Isle of Skye, Scotland. Scottish Journal of Geology 54, 1-12.

591 Rauhut, O.W., 2005. Osteology and relationships of a new theropod dinosaur from the

592 Middle Jurassic of Patagonia. Palaeontology 48, 87-110.

593 Redelstorff, R., Hübner, T.R., Chinsamy, A., Sander, P.M., 2013. Bone histology of the

594 stegosaur Kentrosaurus aethiopicus (Ornithischia: Thyreophora) from the Upper Jurassic

595 of Tanzania. The Anatomical Record 29, 933-952.

596 Reid, R.E.H., 1984. Primary bone and dinosaurian physiology. Geological Magazine 121, $597 \quad 589-598$.

598 Riley, H., Stutchbury, S., 1836. A description of various fossil remains of three distinct 599 saurian animals discovered in the autumn of 1834, in the Magnesian Conglomerate on 600 Durdham Down, near Bristol. Proceedings of the Geological Society of London 2, 397 601399.

602 Rosenbaum, J.N., Padian, K., 2000. New material of the basal thyreophoran 603 Scutellosaurus lawleri from the Kayenta Formation (Lower Jurassic) of Arizona. 604 PaleoBios 20, 13-23.

605 Ruhl, M., Kurschner, W.M., Krystyn, L. 2009. Triassic-Jurassic organic carbon isotope 606 stratigraphy of key sections in the western Tethys realm (Austria). Earth and Planetary 607 Science Letters 281, 169-187.

608 Sadleir R.W., Barrett P.M., Powell H.P., 2008. The anatomy and systematics of 609 Eustreptospondylus oxoniensis, a theropod dinosaur from the Middle Jurassic of 610 Oxfordshire, England. Palaeontographical Society Monographs 160, 1-82.

611 Sereno, P.C., 2012. Taxonomy, morphology, masticatory function and phylogeny of 612 heterodontosaurid dinosaurs. ZooKeys 226, 1.

613 Simms, M.J., 2009. The Permian and Mesozoic. Pp. 311-332 in C.H.Holland and 614 I.S.Sanders (eds), The Geology of Ireland, 2nd Edition. Dunedin Academic Press, 568 pp.

615 Simms, M.J., Jeram, A.J., 2007. Waterloo Bay, Larne, Northern Ireland: A candidate 
616 Global Stratotype Sectio and Point for the base of the Hettangian Stage and Jurassic 617 System. ISJS Newsletter 34, 50-68.

618 Smith, N.D., Makovicky, P.J., Hammer, W.R., Currie, P.J., 2007. Osteology of

619 Cryolophosaurus ellioti (Dinosauria: Theropoda) from the Early Jurassic of Antarctica

620 and implications for early theropod evolution. Zoological Journal of the Linean Society $621 \quad 151,377-421$.

622 Spielmann, J.A., Lucas, S.G., Rinehart, L.F., Hunt, A.P., Heckert, A.B., Sullivan, R.M., 623 2007. Oldest records of the Late Triassic theropod dinosaur Coelophysis bauri. New

624 Mexico Museum of Natural History and Science Bulletin, 41, 384-401.

625 Storrs, G.W., 1994. Fossil vertebrate faunas of the British Rhaetian (Latest Triassic).

626 Zoological Journal of the Linnean Society 112, 217-259.

627 Stumpf, S., Ansorge, J., Krempien, W., 2015. Gravisaurian sauropod remains from the 628 marine late Early Jurassic (lower Toarcian) of North Eastern Germany. Geobios 48, 271629279.

630 Walsh, P.T., 1966. Cretaceous outliers in south-west Ireland and their implications for 631 Cretaceous palaeogeography. Quarterly Journal of the Geological Society London 122, $63263-84$.

633 Warrington, G. Ivimey-Cook, H.C., Cope, J.C.W., 1994. St Audrie's Bay, Somerset, 634 England: a candidate Global Stratotype Section and Point for the base of the Jurassic 635 system. Geological Magazine 131, 191-200.

636 Warrington, G. Ivimey-Cook, H.C., Cope, J.C.W. 2008. The St Audrie's Bay - Doniford 637 Bay section, Somerset, England: updated proposal for a candidate Global Stratotype 638 Section and Point for the base of the Hettangian Stage and of the Jurassic System. ISJS 639 Newsletter 35, 1-66.

640 Welles, S.P., 1984. Dilophosaurus wetherilli (Dinosauria, Theropoda). Osteology and 641 comparisons. Palaeontographica. Abteilung A, Paläozoologie, Stratigraphie 185, 85-180.

642 Whiteside, D.I., Duffin, C.J., Gill, P.G., Marshall, J.E.A., Benton, M.J., 2016. The Late 643 Triassic and Eartly Jurassic fissure faunas from Bristol and South Wales. Palaeontologica 644 Polonica 67, 257-287. 
645 Whyte, M.A., Romano, M., Watts, W., 2010. Yorkshire dinosaurs: A history in two parts. 646 Geological Society of London Special Publications 343, 189-207.

647 Wild, R., 1978. Ein Sauropoden-Rest (Reptilia, Saurischia) aus dem Posidonienschiefer 648 (Lias, Toarcium) von Holzmaden [A new sauropod (Reptilia, Saurischia) from the 649 Posidonienschiefer (Lias, Toarcian) of Holzmaden]. Stuttgarter Beiträge zur Naturkunde, 650 Serie B (Geologie und Paläontologie) 41, 1-15.

651 Woodward, H.B., 1908. Note on a Megalosaurian tibia from the Lower Lias of Wilmcote, 652 Warwickshire. Annals and Magazine of Natural History, series 8, 1, 257-259.

653 Yates, A.M., 2003. A new species of the primitive dinosaur Thecodontosaurus

654 (Saurischia: Sauropodomorpha) and its implications for the systematics of early dinosurs. 655 Journal of Systematic Palaeontology 1, 1-42.

656 Young, C.M.E., Hendrickx, C., Challands, T.J., Foffa, D. Ross, D.A., Butler, I.B.,

657 Brusatte, S.L., 2018. New theropod dinosaur teeth from the Middle Jurassic of the Isle of 658 Skye, Scotland. Scottish Journal of Geology 55, 7-19.

659

660 Figures 


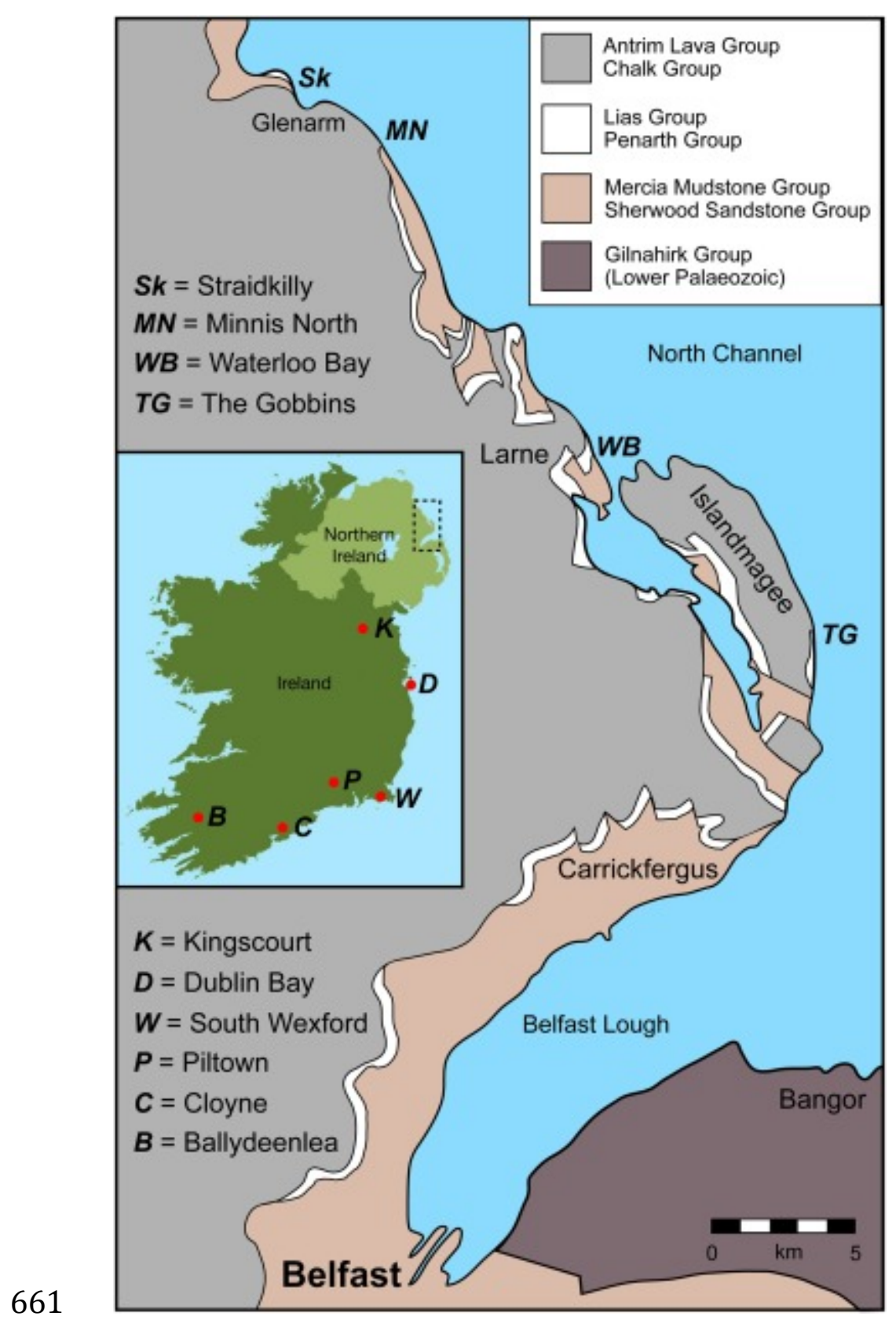

662 Fig. 1. Map of eastern Co. Antrim, with generalised geology, for locations mentioned in 663 the text. $\mathrm{MN}=$ Minnis North; $\mathrm{Sk}=$ Straidkilly; $\mathrm{TG}=$ The Gobbins; WB = Waterloo Bay. 664 Inset: map of Northern Ireland showing location of area covered by geology map. 


\begin{tabular}{|c|c|c|c|c|}
\hline $\begin{array}{l}\text { 号 } \\
\text { 임 }\end{array}$ & & $\begin{array}{l}\text { Maastrichtian to } \\
\text { Santonian }\end{array}$ & \multicolumn{2}{|c|}{$\begin{array}{c}\text { Ulster White } \\
\text { Limestone Formation }\end{array}$} \\
\hline$\frac{\sqrt{\frac{\alpha}{0}}}{\frac{\alpha}{u}}$ & Chalk Group & $\begin{array}{l}\text { Santonian to } \\
\text { Cenomanian }\end{array}$ & \multicolumn{2}{|c|}{$\begin{array}{l}\text { Hibernian Greensands } \\
\text { Formation }\end{array}$} \\
\hline \multirow{5}{*}{$\stackrel{\S}{\frac{丶}{2}}$} & \multirow{5}{*}{$\begin{array}{l}\text { unconformity } \\
\text { Lias Group }\end{array}$} & Sinemurian & \multirow{5}{*}{ 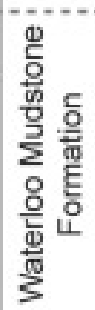 } & Bucklandi Zone \\
\hline & & \multirow{4}{*}{ Hettangian } & & Angulata Zone \\
\hline & & & & Liasicus Zone \\
\hline & & & & Planorbis Zone \\
\hline & & & & "Pre-planorbis beds' \\
\hline \multirow{5}{*}{ 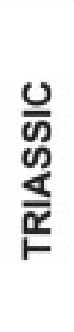 } & \multirow{2}{*}{ Penarth Group } & \multirow{2}{*}{ Rhaetian } & \multicolumn{2}{|c|}{ Lilstock Formation } \\
\hline & & & \multicolumn{2}{|c|}{ Westbury Formation } \\
\hline & \multirow{2}{*}{$\begin{array}{c}\text { Mercia Mudstone } \\
\text { Group }\end{array}$} & \multirow{2}{*}{$\begin{array}{l}\text { Norian to } \\
\text { Ladinian }\end{array}$} & \multicolumn{2}{|c|}{ Colin Glen Formation } \\
\hline & & & \multicolumn{2}{|r|}{ undivided } \\
\hline & $\begin{array}{c}\text { Sherwood } \\
\text { Sandstone Group }\end{array}$ & $\begin{array}{l}\text { Ladinian to } \\
\text { Scythian }\end{array}$ & \multicolumn{2}{|r|}{ undivided } \\
\hline
\end{tabular}

667 Fig. 2. Generalised litho- and chronostratigraphy for the succession exposed on the east 668 Antrim coast. 

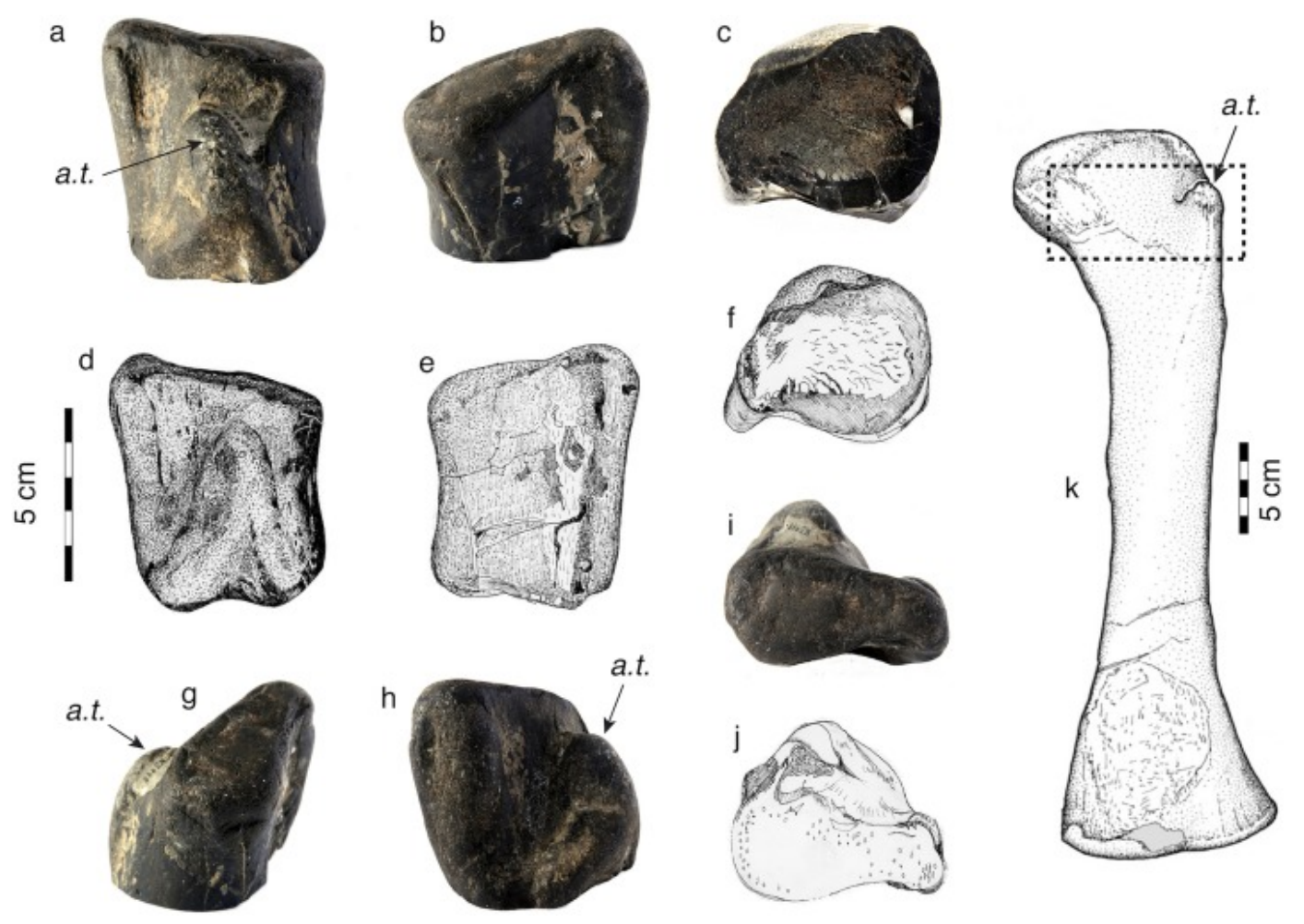

672

673 Fig. 3. Proximal fragment of left femur of thyreophoran ornithischian, cf. Scelidosaurus,
674 BELUM K3998, from The Gobbins, Co. Antrim . Figures d-f, j drawn by Roger Byrne.

675 a.t. $=$ anterior trochanter.

676 a, d. Anterolateral view showing worn but conspicuous anterior trochanter at centre.

677 b, e. Posterior view

678 c, f. Sectioned surface of distal end with dense outer bones surrounding coarse trabecular 679 bone.

680 g. Lateral view, with anterior trochanter on left hand side, below accession number.

681 h. Medial view, with anterior trochanter conspicuous on right hand side.

682 i, j. Worn proximal end viewed from above.

683 k. Anterior view of left femur of Scelidosaurus harrisoni lectotype (NHMUK R1111),

684 with section represented by K3998 outlined (from Norman 2019, fig. 78). 685 


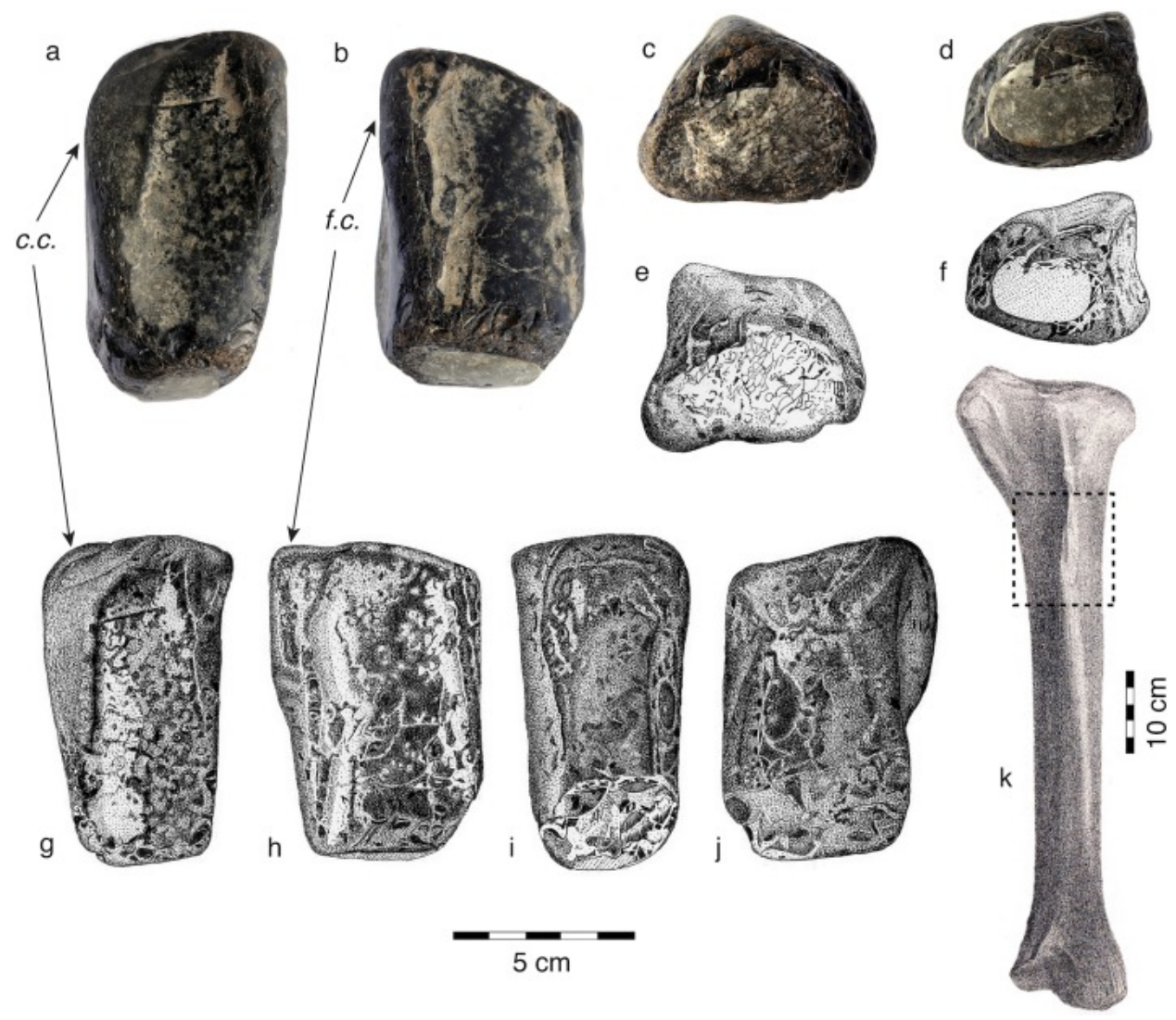

686

687 Fig. 4. Proximal fragment of left tibia of indeterminate neotheropod or megalosauroid 688 theropod, BELUM K12493, from The Gobbins, Co. Antrim. Figures e-h, k, 1 drawn by 689 Roger Byrne. c.c. $=$ cnemial crest; f.c. $=$ fibular crest.

690 a, e. Lateral view showing worn cnemial crest at upper left.

691 b, f. Posterior view, showing smooth outer surface of dense bone (cf. Fig 5a, e).

692 c, k. Proximal end of shaft showing dense outer layer of bone and cavity filled with 693 coarse trabecular bone.

694 d, l. Distal end of shaft showing medullary cavity infilled with grey micritic limestone 695 and with spalled bone fragments in upper part.

696 g. Medial view.

697 h. Anterior view.

698 i, j. Left tibia of Megalosaurus bucklandi with section represented by K12493 outlined 699 (inverted figure of right tibia from Owen 1849-84, P1. 31). 
a

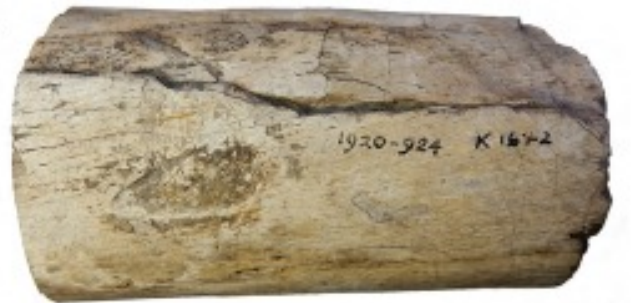

g

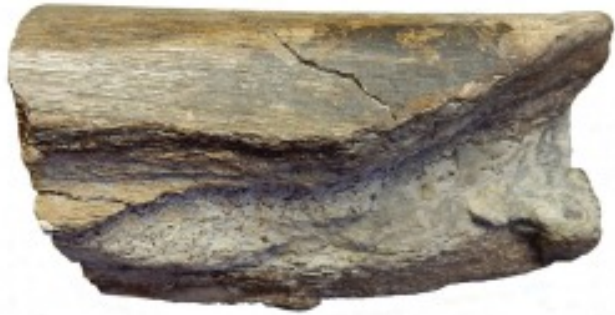

b

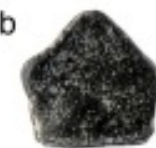

c

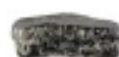

d

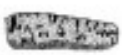

e

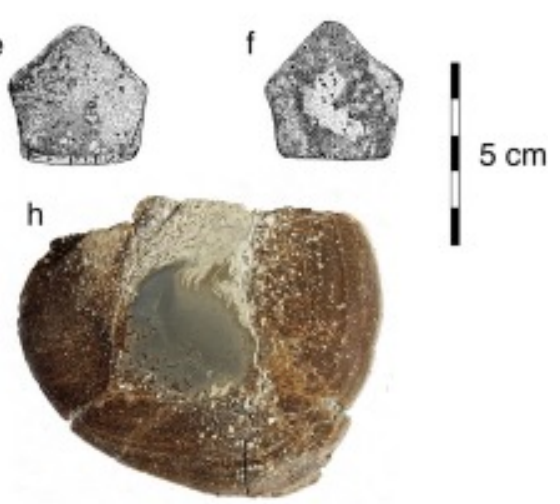

702 Fig. 5. Objects misinterpreted as of dinosaurian origin, from Glenarm and The Gobbins.

703 Figures d-f drawn by Roger Byrne.

704 a. 'Outer' lateral view of BELUM K1642, possibly a fragment of ichthyosaur surangular 705 bone, showing striated bone surface.

706 b-f. Polygonal 'scelidosaur osteoderm' from The Gobbins (BELUM K2015.1.54),

707 reinterpreted as a fragment of basalt.

708 g. 'Inner' lateral view of BELUM K1642 showing striated outer surface and coarse

709 trabecular bone in interior.

710 h. Sectioned end of BELUM K1642 showing outer layer of bone with more conspicuous

711 porosity and LAGs than is typical of dinosaur bones (cf. K3998 and K12493, figs 3c and

712 4c), partial fill of cavity with coarse trabecular bone, and with circumference interrupted

713 by anomalous zone of coarse trabecular bone. Enlarged x1.5 relative to scale. 